\title{
ECONOMIC SITUATION WITH RESPECT TO SUSTAINED YIELD MANAGEMENT ${ }^{1}$ \\ BY J. B. MATTHEWS 2
}

It is understood that the theme of this meeting is a review of progress made in the last ten years toward meeting the forestry objectives set out by this Institute. My assignment is to discuss the economic situation with respect to sustained yield.

I need not confess that I do not qualify as an economist. Further although contrary to custom, I will skip any definition of sustained yield $\ldots$ except to say that any reference will be to the overall forest rather than to any selected segment of it.

I believe at this particular time that we are more concerned with the foundations on which sustained yield or continuous production will be built rather than with the practice itself, and will confine my remarks accordingly.

To review the status of sustained yield against the economic background for all of Canada demands that the subject be treated broadly. I propose, then, merely to indicate progress in the past decade toward providing these foundations and to sketch the economic factors affecting such progress.

The last ten years has brought us from mid-war time to what might well come to be recognized as the end of the first post-war period. It has not been what we expected. Instead of the anticipated public works for rehabilitation and for relief of unemployment, we have enjoyed full employment and so-called boom times. It is a healthy condition that whatever progress in forestry has been made, has been on a competitive basis, and not as subsidy or relief measures.

The basic economic fact of forest management is that money to perpetuate and manage the forest must come from the sale price of the product in the long run. In the last ten years we have been able to do this, and progress in the next decade will depend on our ability to continue the process.

Forest industries in the decade have set new records for forest production, manufacture, employment, value of products, volume of exports, value of purchases and apparent profit.

But the economic situation cannot be measured entirely by any or all of the impressive statistics which I haven't quoted but which are no doubt familiar to you.

During the same period money flowed, also at record levels, from the forest industries to the Federal Government as taxes, and to Provincial Governments in the form of taxes, stumpages and carrying charges. Wage rates in the woods have tripled in the decade and in pulp and paper mills have gone up 150\%. Freight rates have doubled, carrying charges have increased-in some cases to more than double-and stumpages have increased generally and in a specific case by more than $400 \%$. Generally speaking, government revenues from the forest and from the woods-using industries have been buoyant and at an all-time high.

The forest industries, by and large, came through the war with plants

I A Paper prepared for the 1953 Annual Meeting of C.I.F. at Winnipeg.

2 Abitibi Power and Paper Company. 
demanding improvement, modernization and replacement of obsolescence. Heavy expenditures have been necessary, and these have become increasingly so with the spiralling cost of every item.

Within this economic climate of high production and high cost where do we stand regarding sustained yield?

The first essential for sustained yield is a profitable market in which to sell that yield and thereby derive money to sustain it.

To create, invade and hold markets, we must have a quality product sold at a fair price. The forest industries as a whole have made great strides in bringing their physical plant to a high degree of efficiency, and it is fair to say that they produce quality products. The cost structure has, however, reached a danger point, and there has been some indication of falling demand for both raw wood and finished product, and softening of prices as well. Canada sells the bulk of its export goods, including forest products, in a single market, which is also the home of a tremendous woods-using industry, and thus is most vulnerable to internal and external policies of one nation. I won't take the time here to point out the signs, but the writing is on the wall for anyone to read.

We may well be at a turning point where we will find it a struggle to hold the markets we have, and a long uphill job to invade new ones because of our cost price structure, and because both our competitor countries and our potential customers are seeking to improve their own self-sufficiency in forest products.

I leave it to you to decide how sound is the economic foundation for sustained yield. If demand should fall off materially, we may find ourselves in the position of anyone on a tight budget who must ask the two questions: "Do I need it?" and "Can I afford it?"

A second essential for sustained yield - some might put it first - is protection of the forest from its enemies.

The decade has seen great progress in protection, with expansion in the services for protection from fire, insects and disease. The work done in the fight against budworm has made headway, in the long-term tedious part of the job as well as in the more spectacular spraying jobs which serve to highlight the spirit of co-operation between government and industry which has been a prominent feature of the advances made in protection. Not the least important feature has been the acquisition of more adequate and competent personnel and the upsurge of training schemes applicable to protection.

It is axiomatic that a forest cannot be managed unless it can be reached. Nor can it be properly protected from all of its enemies.

Lack of access will have much to do with the kind of forests we shall deal with in the future, and the extent to which we can affect their value when they finally become accessible.

The forest industries have done a remarkable job in building roads. A figure I read recently mentioned 1600 miles of road built in the last ten years. That is a lot of road - and it took a lot of somebody's money — but it is still a drop in the bucket. Much of the forest we talk of managing for sustained yield won't even be reached for decades at the present rate. 
For the most part, and the trend to a change is just becoming apparent, the provinces as forest owners have been reluctant to provide access roads in the forest, particularly if these are under lease or license. This job has been left to the forest operator, who either just haven't got the kind of money needed for the job, or cannot see his way clear to investing for a distant future return when he has no security of tenure. Under present conditions whereby the crop which is removed must bear the cost of its own access, half a rotation or more must elapse before our so-called accessible forest becomes accessible to the forest manager.

In spite of the progress that has been made, I would say that this part of the foundation was just nicely started - with say the footings in - and the reasons are almost entirely economic.

Forestry inventory is basic to sustained yield managemnet. More headway has been made in this field in the decade than in all our previous forest history. The development of new methods, particularly in photography and photogrammetry, have revolutionized the job and made overall inventory, and the necessary periodic re-inventory, possible within an acceptable period of time. The buoyancy of government revenues and industries' financial condition has made this progress possible.

I will mention another essential for sustained yield, and that is regeneration after logging or fire or both.

Here we have done the basic job of fact-finding. Regeneration surveys and studies have enabled an appreciation of the nature and extent of the problems. The next job is to relate cause and effect, to find out the "why" and discover cures that can be applied practically. Research is going on through many agencies and some of the answers are coming up now. It's a long-term job and we'll probably never know all the answers. Some are not waiting for the answers, but are planting, or otherwise treating denuded areas now.

Many large-scale planting operations are underway on cut-over, burned over and cleared lands. Such techniques as scarification, lopping and scattering slash for purposes of regeneration, patch and strip loggging, etc., have made their appearance in the woods. There are numerous examples of intensive forestry practices and several experimental forests. These indications, however, are probably the exception rather than the rule if the whole forest picture of Canada is examined.

The entry of the Dominion Government into the field of forest assistance, though late and little, is welcome, and it is to be hoped that the scale of its participation is to be increased either directly or indirectly for the perpetuation of the forest is a job for all Canadians and not merely for those most closely concerned.

To sum up, I would suggest that at the end of our most prosperous decade we have made some headway in laying the foundations for sustained yield forestry but paradoxically stand in some danger of pricing ourselves out of our markets - perhaps through that very prosperity.

Furthermore, unless the woods-using industries are able to bring down 
their costs, and don't forget that those costs include stumpage and taxes of all kinds - and unless a greater part of both can be returned to the forest, I suggest that we may be unable to keep up the rate of progress already attained. 